\title{
UHRIN DOROTTYA
}

\author{
ANTIOCHIAI SZENT MARGIT LEGENDÁJA \\ A SZALONNAI REFORMÁTUS TEMPLOM FALKÉPEIN ${ }^{1}$
}

Antiochiai Szent Margit tisztelete feltehetően csupán a 11. század legvégén jelent meg Magyarországon, a kultusz elterjedésében pedig jelentős szerepet játszhatott Álmos herceg a meszesi monostor és a dömösi prépostság alapításával. ${ }^{2}$ Ekkor azonban még nem rendelkezünk sok adattal a szent tiszteletét illetően; úgy tünik, hogy Szent Margit csak a 12-13. század fordulóján vált valóban népszerüvé. Ez időtől kezdve több, neki szentelt egyházat és monostort is alapítottak (például Csurgó, Pornó, Hatvan). ${ }^{3}$ Ebből a korszakból azonban nem maradtak fenn a szentet ábrázoló müvészeti alkotások. Szent Margit legkorábbi magyarországi ábrázolásai a 13. század második feléből származó szalonnai és süvetei falképeken láthatók. Tanulmányomban a szalonnai református templom Szent Margit-ábrázolásaival foglalkozom, és megpróbálom értelmezni a jeleneteket a feliratok és a szent legendájának egyik legkorábbi verziója alapján.

\section{A szalonnai Margit-legenda a szakirodalomban}

A szalonnai református templom egy Árpád-kori rotunda bővítésével keletkezett. Az eredeti kerektemplomot a 12-13. század fordulóján építették, a 13. század második felében pedig szabálytalan négyszögű, igénytelen kialakítású hajóval bővítették nyugat felé. A töredékesen megőrződött, Szent Margit-legendát ábrázoló falképek a templom szentélyeként használt rotunda déli falán maradtak fenn (1. kép). ${ }^{4}$ A falképeket 1922-es megtalálásuk után elsőként Leszih Andor, majd néhány évvel később Szabó Ferenc ismertette. A feltárás után lényeges beavatkozás nem történt a falképeken, csak 1951-ben restaurálta azokat Bartha László. ${ }^{5}$ A templom 1972-ben kezdődő régészeti kutatása és müemléki helyreállításának részeként a falképeket megtisztították, konzerválták és - vonalkázott technikával - kiretusálták. ${ }^{6}$ Az Árpád-kori falképek al secco technikával készültek, száraz vakolatra festették őket, így különösen sérülékenyek. 2000-ben javították ismét a templomot és védték meg a további vizesedéstől a falképeket hordó falakat. ${ }^{7}$

Az Árpád-kori rotunda számon tartott emléke a 13. századi müvészet történetének Magyarországon. A korszakmonográfiákban, az épülettípust feldolgozó tanulmányokban és a topográfiai munkákban is régóta szerepel. Töredékesen fennmaradt falképei is fontos emlékei középkori müvészetünk történetének. Falképek (három apostol-alak) már a 20. század elején felbukkantak a templomban - Myskovszky Viktor akvarellmásolataiból ismerjük őket -, ezek azonban utóbb elpusztultak. 1922ben a templom renoválása során kerültek elő az Árpád-kori falképek, vagyis az Antiochiai Szent Margit legendáját bemutató falképciklus töredékei. Bár erről a sorozatról kevés önálló, részletes tanulmány született, a müvészettörténeti összefoglalások kötelezően tárgyalják, stílustörténeti vagy ikonográfiai aspektusból. Az öt kiadást megért „,kétkötetes" müvészettörténeti kézikönyvben Dercsényi Dezső írt róla; ${ }^{8}$ a régi magyar művészetről szóló rövid összefoglalásában Kampis Antal. ${ }^{9}$ Az 1984-ben publikált egykötetes művészettörténetben Marosi Ernő, ${ }^{10}$ a 2001-ben megjelent egyetemi tankönyvben pedig Wehli Tünde pozícionálta. ${ }^{11}$ Legutóbb ismét Marosi Ernő írt róla röviden a hazai romanika müvészetét bemutató kismonográfiájában. ${ }^{12}$ GerversMolnár Vera is regisztrálta a szalonnai rotundát a müfajról írott, ${ }^{13}$ Marosi Ernő pedig a magyar falusi 


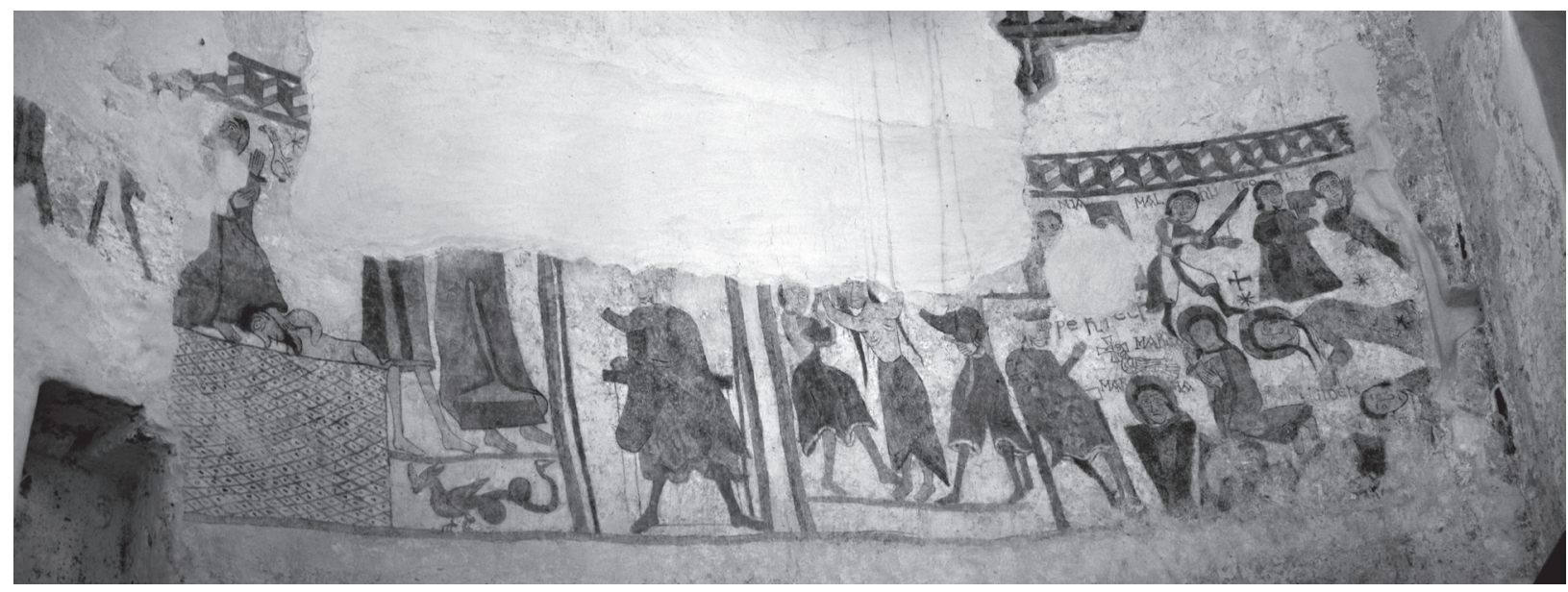

1. Antiochiai Szent Margit legendája a szalonnai református templom szentélyének déli falán (a szerző felvétele, 2018)

templomokat tárgyaló összefoglalásában. ${ }^{14}$ A Borsod megye múemlékeit bemutató kötetben is helyet kapott, Détshy Mihály pontos leírásában. ${ }^{15}$ A középkori freskókat feldolgozó kötetekben is szerepelt, még a szlovákiai múvészettörténet-írásban is, már csak a közeli Süvete (Šivetice, Szlovákia) miatt is, analógia gyanánt. ${ }^{16}$

A frissen feltárt falkép elsőként Leszih Andor (1880-1963) - kitűnő helytörténész, a Borsod-Miskolci Múzeum munkatársa, később igazgatója ${ }^{17}$ írta le 1922-ben. A Magyarság címú napilapban egész oldalas cikkben számolt be a felfedezésről, és - Bartus Ödön rajza után készült - reprodukciót is közölt róla. ${ }^{18}$ A Szent Margit-ciklus - egy méter magas, három és fél méter széles - maradványa a templom teljes körú javítása közben bukkant elő. Leszih ismerte föl a témát: a töredékes ciklus első jelenetében Margit legyőzi a kísértő sátánt (a fejére tapos), a következőben két figurának csak az alsó része látható (valószínúleg Margitot a poroszló Olibrius elé vezeti), alattuk kígyófarkú szörnymadár. „A következő, vonallal elkülönített falfelületen a magas trónuson ülő hatalmasság alakja van megfestve, a mellette levőben pedig amint a derékig meztelenre vetkőztetett szentet ketten ostorozzák. A következő csoportozatban a trónuson ülő helytartó előtt szájában keresztet vivő galamb, lejjebb a fekvő és kezét felemelő Margit (kétszer is jelezve: MARGA), fentebb a mártír Perfectus (?), kardot tartó Malkhus és a Margitot letaposó Theophilos (...) képe van roppant primitív módon és teljesen bizánci előadási modorra emlékeztető stílusban festve, a nevek bizánci módon mindig az illető feje mellé írva, jellemző XII. századi betűkkel."

Szabó Ferenc miskolci festőművész, rajztanár 1936-ban írott művészettörténeti disszertációjában feldolgozta Borsod megye Árpád-kori templomait. ${ }^{19}$ Ó újabb eredményekre jutott a falkép értel- mezését illetően: felismerte, hogy a sárkány a szent legendája szerint a börtönben jelent meg neki. A Teofil nevű alak esetében megállapította, hogy Szent Dorottya legendájából kerülhetett Szent Margit legendájába, és a jobb felső alak ugyanebből a legendából való angyal lehetett, aki rózsákat és almákat hozott Teofilnak. ${ }^{20} \mathrm{~A}$ képeket mindkét ismertetője a 13. század közepére, második felére datálta.

A szalonnai ciklus múvészettörténeti helyét elöször Gerevich Tibor - a disszertációt jegyző Szabó Ferenc professzora - határozta meg a magyarországi romanikát feldolgozó nagymonográfiájában. Nem volt jó véleménnyel róluk. „Igen kezdetleges ábrázolások, az alakok fehér alapon, meglehetősen rendszertelenül helyezkednek el. Különösen az arcokból azt lehetne sejteni, hogy keleti, örmény kódexminiatúrák hatása alatt készültek, aminek nem mondanak ellent a latin feliratok és az egyik helyen fennmaradt román ízlésü, széles geometrikus keretdíszítmény, mert hiszen a falképek múvészi tudást nélkülöző, kezdetleges kompilációk." ${ }^{21}$ Gerevich nagy reményü tanítványa, Kampis Antal is ebben a szellemben említette meg az általa 1200 körülre datált Szent Margit-ciklust a középkor müvészetet bemutató, reprezentatív összefoglalásban, a Domanovszky Sándor szerkesztette Müvelődéstörténet első kötetében (1939). ${ }^{22}$ Már a háború után, 1954-ben Radocsay Dénes a középkori Magyarország falképeinek teljességre törekvő monográfiájában lényegesen nem tért el a korábbi irodalomtól. ${ }^{23}$ Megengedhetőnek tartotta a még korábbi datálást: „A csekély töredékekből, a naiv, a művészi gyakorlat hiányát mutató formálásból nehéz a datálásra vonatkozó pontos következtetésre jutni, a töredékek felső szegélyén fennmaradt néhány betű formája s ugyanitt a keretező dekoratív dísz hihetővé teszi a XII. századi keltezést is." 1957-ben Leszih Andor visszatért a szalonnai falképekhez, és néhány 
ponton korrigálva korábbi híradását, leírta a legendajeleneteket. A legendaábrázolás hat részre osztható: az első (1) nagyrészt elpusztult, a következő képen a mezőn libákat legeltető Margitot látja meg Olibrius, a római praefectus, és meg akarja szerezni magának (2), ám Margit visszautasítja közeledését, amit úgy szimbolizált a festő, hogy Margit az őt kísértő sátánnak a fejére lép. Majd (3) a leendő szentet Olibrius elé vezetik (lába alatt egy sárkány), aki a következő (4) képen helyezkedik el. Az ezt követő (5) képen Margitot megvesszőzik, az utolsó (6) rész pedig Margit dézsában való kínzását és végül lefejezését mutatja be. Egyes képek mellett rövid feliratok olvashatóak, Leszih Andor néhányat közölt is: a hóhért MAL I HUS, a könyvet fogó alakot pedig TEOFI, Theophilos névvel oldotta fel, Margit nevét pedig MARGA alakban adta meg. ${ }^{24}$

Az Árpád-kori falfestészet történetét monografikusan feldolgozó Tóth Melinda foglalkozott ismét bővebben a falképekkel (1974). Elődeihez hasonlóan ő sem volt jó véleménnyel a falképek kvalitásáról. Falusias, szinte népies a hangvétele - írta -, feltünő a kompozíciós érzék hiánya, és a "térbeli és ikonográfiai konfúzió az utolsó alakok puszta azonosítását is megnehezíti". Az első két jelenet (1-2) a gonosz legyőzését jeleníti meg, Margit egy szakállas figurát a földre tapos. Ezután (3) Margitot Olibrius elé vezeti egy poroszló, alatta a Gonosz kígyó formájában jelenik meg. Majd (4) megostorozzák Margitot. Innentől az ábrázolások egymás fölött két mezőben folytatódnak. A felső sor első jeleneténél (5) két alak látható, alattuk a PERFECT szó olvasható, de így sem lehet értelmezni, mellettük (7) egy Teofil nevư alakot papírral és tollal a kezében ábrázol a festő. Tóth Melinda úgy vélte, hogy Szent Dorottya története mellett Mária legendájából is átkerülhetett a Teofil-jelenet Margit ciklusába, ${ }^{25}$ egy lábjegyzetben azonban megemlítette, hogy ugyan a Margit-legenda szerzőjének is Teofil a neve, de "túlságosan merész" dolog lenne a szerző megjelenítését feltételezni a ciklusban. ${ }^{26} \mathrm{~A}$ nagyméretú karddal felvonuló poroszlót a "Malchus” névvel látta el a festő, ezt Tóth Melinda krisztológiai ciklusból eredeztette. ${ }^{27} \mathrm{Az}$ utolsó jeleneteken a kivégzés előtt imádkozó, majd a kivégzett szent dicsfényes alakja látható azoknak a fejeivel együtt, akik vele együtt szenvedtek vértanúhalált. A falkép megrendelőjét Örsúr nembeli Miklós fia, vagy valamely unokája személyében tartotta keresendőnek.

A templom 1972-ben kezdődő régészeti kutatása, majd műemléki helyreállítása lezárását követően Hokkyné Sallay Marianne írt a falképekről 1981-ben. Úgy látta, hogy a Szent Margit-legenda nemcsak a szentély déli falán, hanem az apszisban is futott. Az ő interpretációjában a jelenetek a következők: az első (1) kép nagyrészt elpusztult, ezen vagy azt ábrázolhatták, amikor Olibrius először meglátja Margitot, vagy amikor maga elé rendeli. A következő jelenet (2) a gonosz legyőzését mutatja be, felette a Szentlélek galamb formájában jelenik meg, ezután (3) a poroszló Olibrius elé vezeti Margitot, és (4) a prefektus trónon ülve elrendeli az (5) ostorozást. Ezek után a jelenetek két sorban folytatódnak, Sallay Marianne az alsó sor olvasásával folytatja: ennek első jelenetében (6) Olibrius előtt a szentet olajban fözik. ${ }^{28}$ Felette (7) két alak a NIA és a PERFECT felirattal, de a jelenet értelmezhetetlen. A következő jelenet (8) két sort betölt: a felső sorban Margit hóhérját ábrázolják, akit Sallay Marianne szerint MARCHUS névvel látott el a festő, Margit pedig térden állva imádkozik kivégzése előtt. Ezután (9) Teofil alakját láthatjuk Dorottya vagy Mária legendájából, majd (10) a szent látható, valamint - töredékesen - a vele együtt vértanúságot szenvedők fejei. A régészeti feltárás eredményeként a szerző és M. Kozák Éva tovább pontosította a templom bővítésének és a falképek elkészültének időpontját: Sallay Marianne a bővítés megrendelőjét Tekus fia István mester személyével azonosította, és az elkészültét az 1270-es 1280-as évekre tette, mivel ebben az időben István egyre magasabbra emelkedett a ranglétrán. Úgy tudta, nádor volt, ${ }^{29}$ azonban csak a beregi és pataki ispánságig jutott. ${ }^{30}$ A két szerző úgy vélte, hogy az 1270-es évek előtt már készen kellett lenniük a falképeknek, mivel a templom átalakításakor a diadalívhez festett vakolatos középkori téglát használtak fel, amelynek díszítése megegyezik a Szent Margit-legendáéval. ${ }^{31}$

\section{A Theotimus-féle passio és a szalonnai legenda viszonya}

A falfestményekkel foglalkozó szakirodalom ikonográfiai elemzéseit a Szent Margit-legenda különböző verzióinak tanulmányozása után ki lehet egészíteni. Főként a falképen szereplő nevek segítenek abban, hogy megállapítsuk, hogy a legenda melyik verziója szolgálhatott alapul a falképhez. Ehhez azonban újra meg kell vizsgálni a feliratok egy részét. A vizsgálatot a Teofil felirattal érdemes kezdeni, mivel ez látszik Margit legendájától a leginkább idegennek. A Szent Dorottya-legendából való kölcsönzés igen valószínűtlennek tünik, tekintve, hogy a 13. században Szent Dorottya kultuszának semmi jele nem volt még az országban, sőt a szent Nyugaton sem volt túl népszerü ebben az időben. Szent Dorottya kultusza csupán a 14. század első felében terjedt el Nyugat-Európában. Magyarországon 


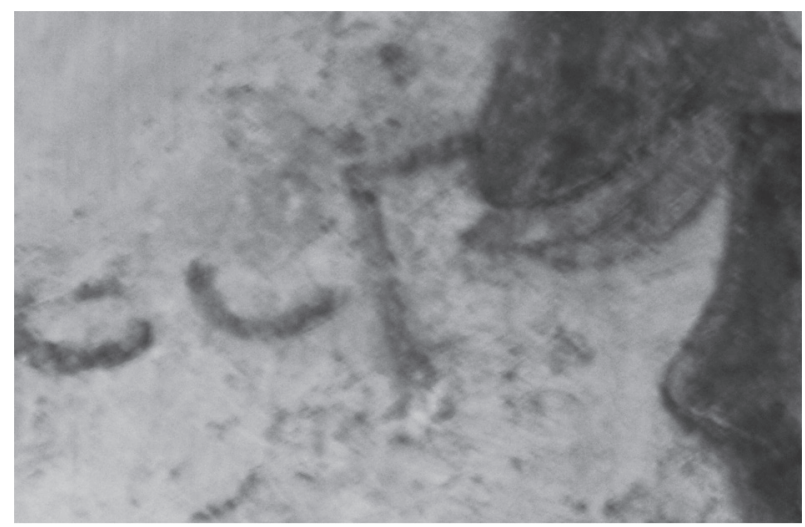

2. A PERFECT szó szóvégi T betüje

ugyan már a 14. század második felétől találkozhatunk a kultusz különféle jeleivel, de leginkább csak a 15. századtól mondhatjuk népszerünek a szentet. ${ }^{32}$ A szalonnai falkép tüzetesebb tanulmányozásakor észrevehető, hogy nem TEOFIL felirat szerepel a falon, hanem félreolvasásról van szó: a TEOTI[...] név látható az alak fölé írva. A két betü összetévesztését az okozhatta, hogy a falképeken a szóeleji T máshogy néz ki, mint a szóközepi és szóvégi. Egy, a falképen szereplő másik szóval ez bizonyítható, hiszen a PERFECT szó szóvégi T betüje megegyezik a TEOTI[...] második T-jével. Így a Teofil név

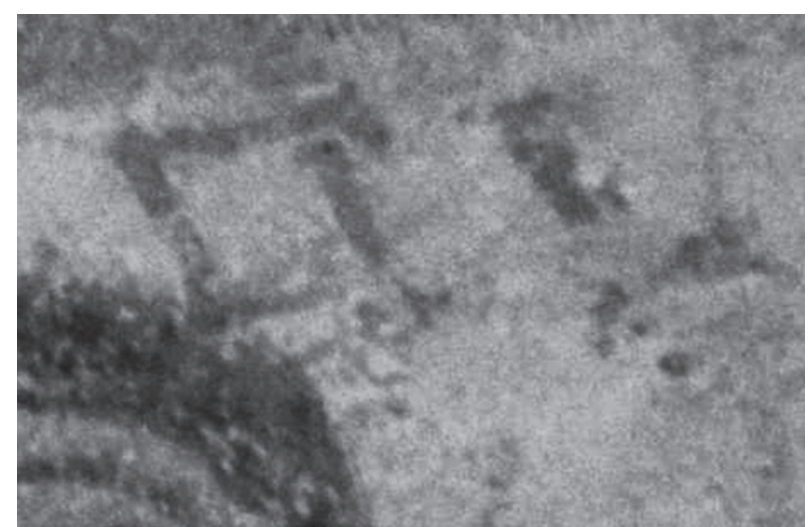

3. A TEOTI név TI betükapcsolata

helyett Teoti[...] olvasandó, ami a Theotimus névre utal (2-3. kép). A pribék mellett pedig a korábbi szakirodalom egy részében MARCHUS-nak ${ }^{33}$ olvasott szó MALHU-ként szerepel a falképen, amely minden bizonnyal a Malchus névre utal.

A Theotimus és a Malchus név együttes előfordulása világít rá, hogy a falképek (vagyis sokkal inkább azok előképei) Szent Margit legendájának egy korai verziója alapján készültek, amely szerint egy Theotimus nevü keresztény táplálta a szentet a börtönben, és később ő jegyezte le történetét (Passio a Theotimo) is. ${ }^{34}$ A Theotimus-féle passio a legrégebbröl

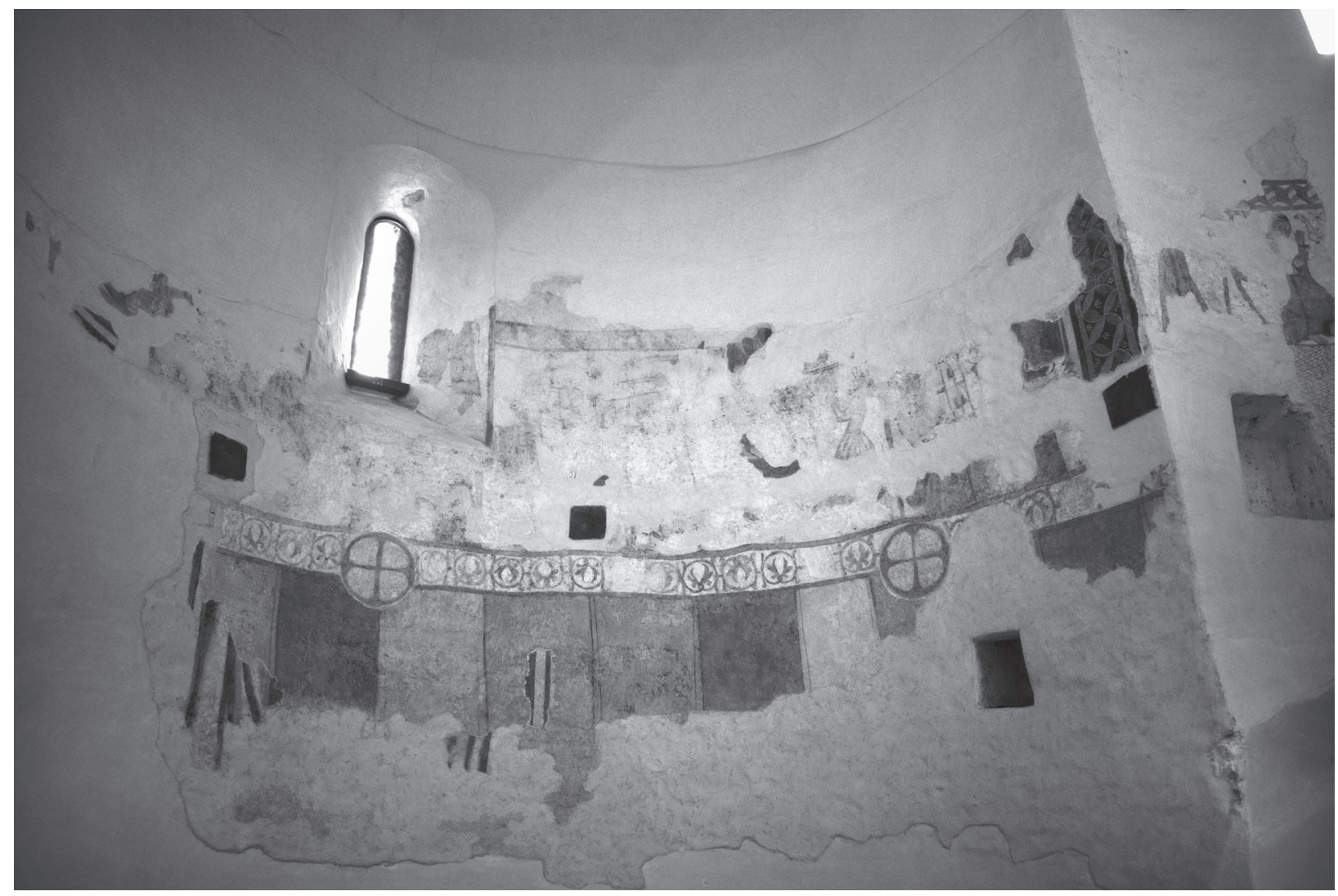

4. A szentély töredékes jelenetei 


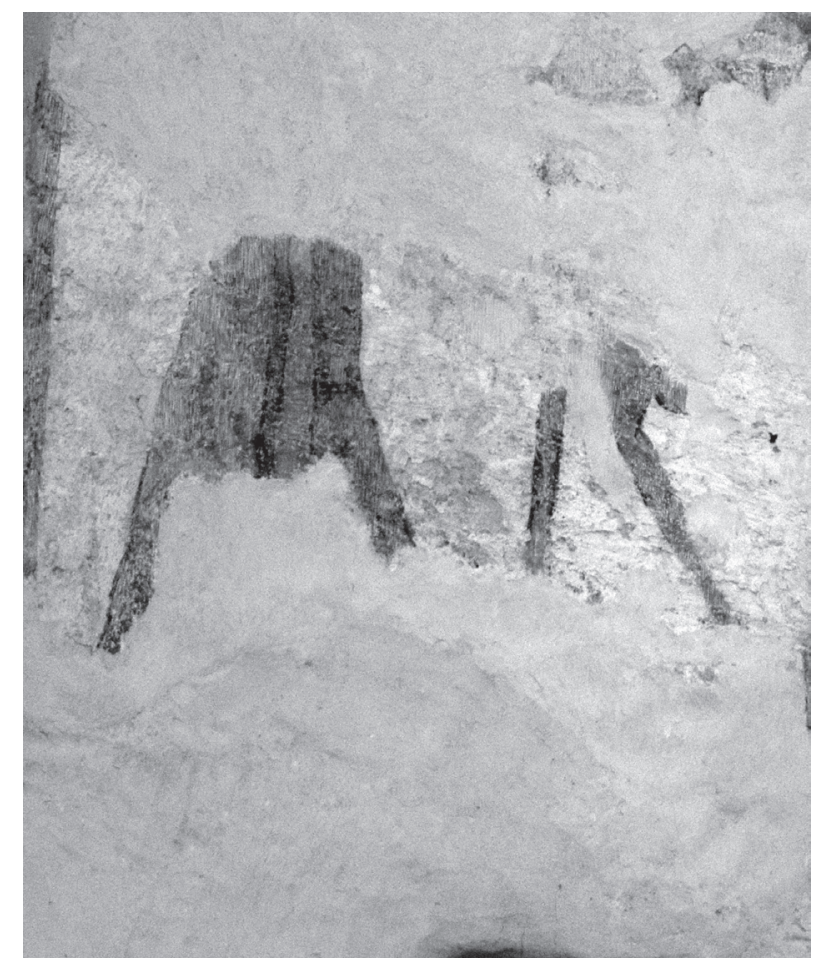

5. A falkép elsó, azonosithatatlan jelenete (a sárkány legyözése vagy a gonosz megjelenése)

(feltehetően a 9. század előtt keletkezett) fennmaradt görög nyelvű legenda, amely később nyugaton is elterjedt latin nyelven. ${ }^{35} \mathrm{E}$ legendaverzió szerint valóban egy Malchus nevü ember fejezte le a szentet (vagyis a krisztológiai utalás az írott legendából származik, nem a kép festőjétőll). Az, hogy egy Szent Margit-legenda ábrázolás Theotimust is megjeleníti, nem párhuzam nélküli. A Margit-legenda egyik legkorábbi ábrázolásán az első jelenetben Mária és Margit Krisztus előtt helyezkednek el, mellettük pedig Theotimust látjuk, munkájában elmerülve. ${ }^{36}$ Egy, a 13. század második feléből származó veronai kódex Szent Margit-ciklusa pedig ábrázolja azt a jelenetet, amikor Theotimus és a dajka meglátogatja Margitot a börtönben. ${ }^{37}$ Egy késő 13. századi itáliai kódex (jelenlegi lelőhelye: Princeton University Art Museum, 1952-57.) utolsó jelenete pedig szintén a legenda lejegyzőjét ábrázolja könyvvel a kezében. ${ }^{38}$

Az írott legendaverzió alapján sokkal könnyebben követhetővé válnak a jelenetek is. Például, miután két sorra bomlik a falkép, a felső jelenethez kötött PERFECT szó valószínúleg inkább az alsó képhez tartozik és Olibriusra utal, aki prefektus volt: ebben az esetben elírásról lehet szó: ${ }^{39}$ talán a felirat írója nem ismerte a prefektus szót, és az általa ismert, hasonlóan hangzó szót írta fel. A NIA felirat alatti jelenet pedig talán azt mutathatja be, mikor Margit dajkája és Theotimus vizet hozott a börtönbe. ${ }^{40}$ Valószínü, hogy a falképeknek csak nagyjából

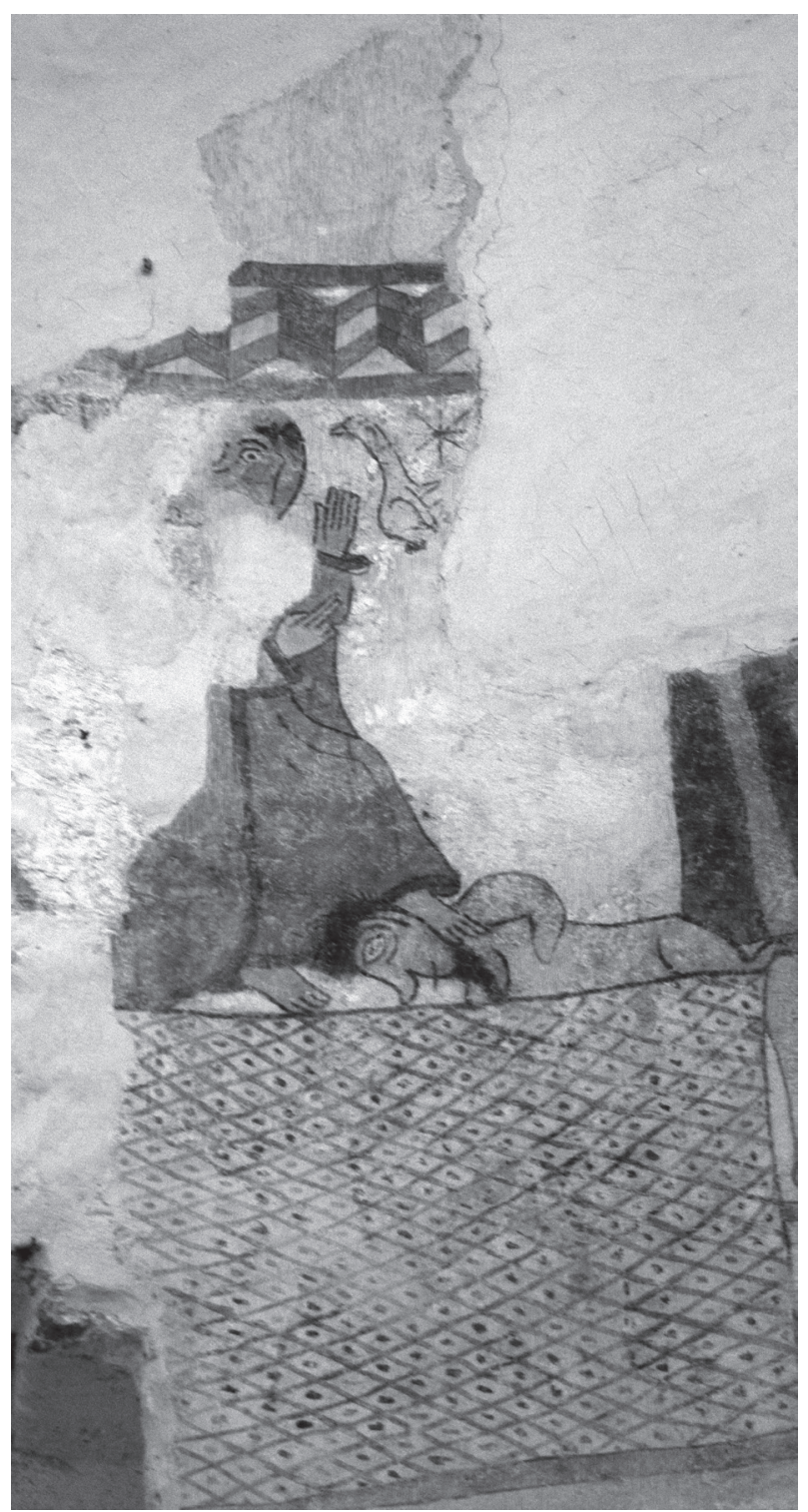

6. Szent Margit eltapossa az ember formájú gonoszt

a fele-kétharmada maradhatott meg, mivel a történet közepén kezdődnek a jelenetek. Már Tóth Melinda is felvetette annak a lehetőségét, hogy nem került elő az összes falkép a szalonnai Szent Margitlegendából, ${ }^{41}$ Sallay Marianne pedig amellett érvelt, hogy az apszisban kezdődött a legenda. ${ }^{42}$ Összevetve a legenda szövegét és a nagyjából azonos időben keletkezett narratív ábrázolásokat (a Theotimus-féle verzióról) ${ }^{43}$ a szalonnai falképekkel, valószínűnek tưnik, hogy legalább további három, de valószínüleg még több jelenet szerepelt az apszisban, amelyek mára igen töredékesen maradtak meg. (4. kép) Kiterjedésben és korban a veronai és a princetoni kódexek ábrázolásai állnak a legközelebb a szalonnai falképekhez. A veronai kódex ciklusa huszonegy jelenetből áll, ebből tíz ábrázolás szerepel a démon legyőzése előtt, ${ }^{44}$ a princetoni kódex huszon- 


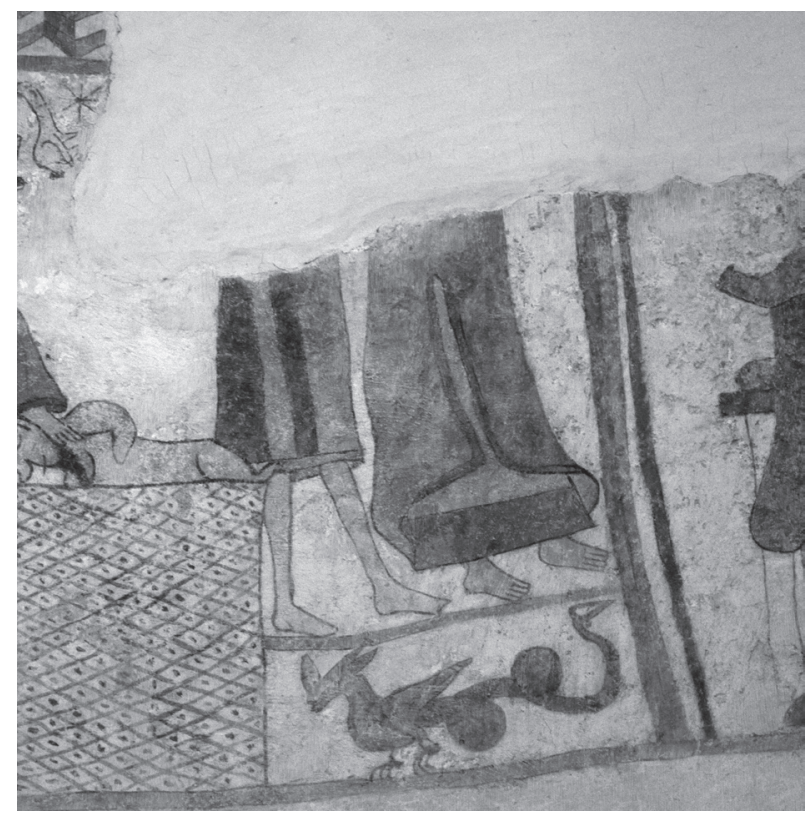

7. Szent Margitot a helytartó elé vezetik

három jelenetéből Margit a tizenegyediken győzi le a démont. ${ }^{45}$ Vagyis a gonosz legyőzése a legenda (és az ábrázolások) kellős közepén szerepel. A legenda alapján a hiányzó történetelemek a következők lehettek: (1) Olibrius meglátja Margitot, miközben a lány bárányokat legeltet, (2) Olibrius meg akarja szerezni magának Margitot, majd vitatkoznak, (3) Margitot börtönbe zárják, (4) az első nap a börtönben, Margitot kínozzák különböző módszerekkel. Azt immár sajnos lehetetlen rekonstruálni, hogy ezeket a történet-elemeket hány jelenetben mutatta be a szalonnai falkép festője, ám a szöveges és a képzőművészeti párhuzamok alapján igen valószínúnek tûnik, hogy számos jelenet elpusztult.

Érdemes az alábbiakban újra áttekinteni a legendát követve a jeleneteket. A történet balról jobbra tart, a falkép sávját felül parallelogrammákból és rombuszokból kialakított, térhatású szalag zárja le. A szentély felől induló jelenetsor első jelenete (1) igen töredékes. Két figura részlete látható rajta, erősen retusált állapotban (5. kép). Mivel a következő jeleneten (2) az ember formájú gonoszt győzi le Szent Margit, ez a kép talán a gonosz megjelenését vagy a sárkány legyőzését mutathatta be. Az írott legendaverzió szerint a gonosz először sárkány képében jelenik meg, majd azután emberként. Nem találtam párhuzamot arra, hogy először ábrázolták volna az ember-gonosz, majd utána a sárkánygonosz megjelenését, így feltehető, hogy ez a jelenet Margitot és a sárkányt vagy az ember formájú démon megjelenését mutatta be. ${ }^{46} \mathrm{~A}$ következő (2) képmező alsó részét rombuszmintás rácsháló tölti ki, ennek felső peremén jobbra mezítelen, szakállas

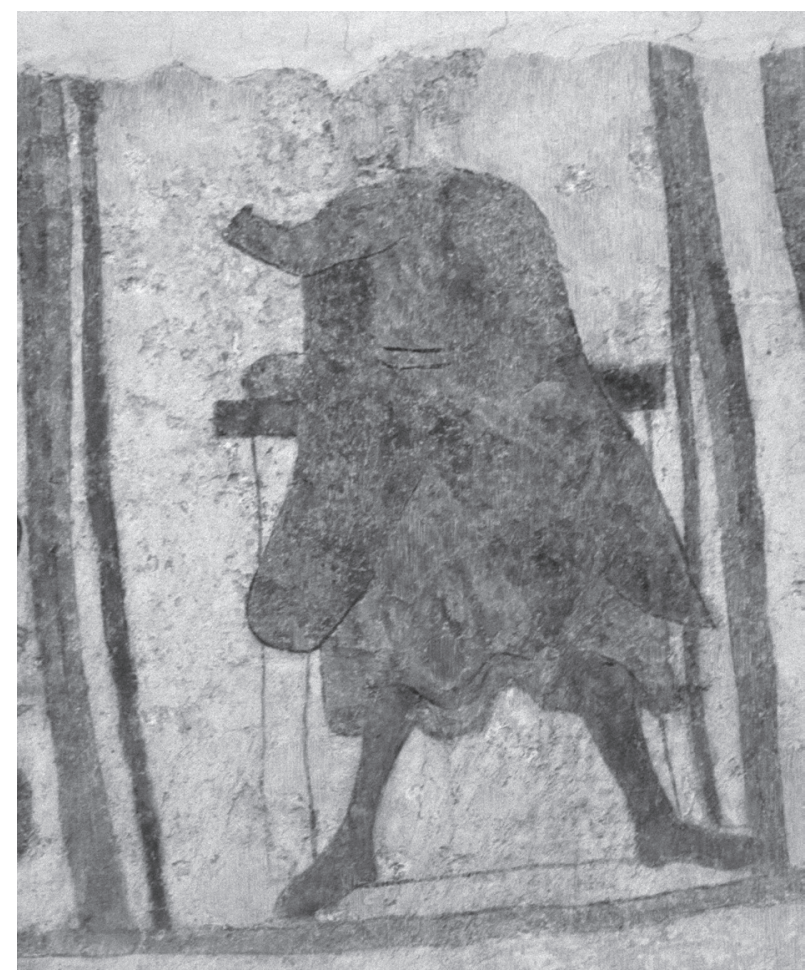

8. A helytartó alakja

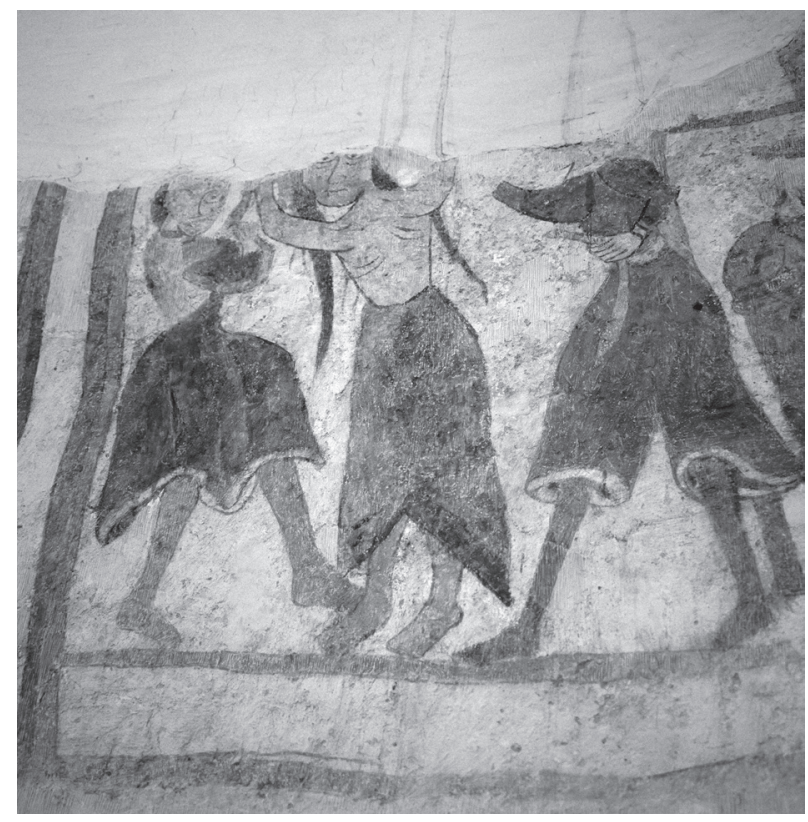

9. Szent Margitot megvesszőzik

figura fekszik, nyakán tapos a sárgaruhás, kékköpenyes szent. Mindkét kezét felemeli, előtte fehér színű madár lebeg, mögötte nyolcágú, küllős csillag (6. kép). A legenda szövege: „Ekkor Szent Margit megragadta a démont a hajánál fogva, és a földre terítette, jobb lábát a nyakára téve így szólt: Távozz az én szüzességemtől. Midőn ezeket mondta... egy galamb telepedett rá és így szólt: Boldog Margit, 


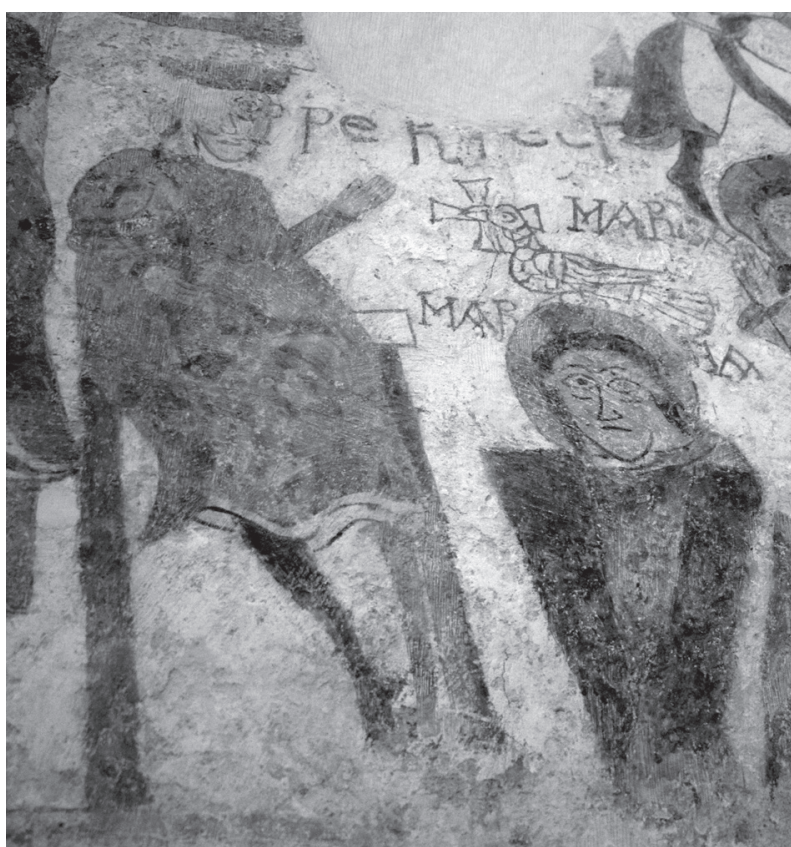

10. Szent Margit megkínzása

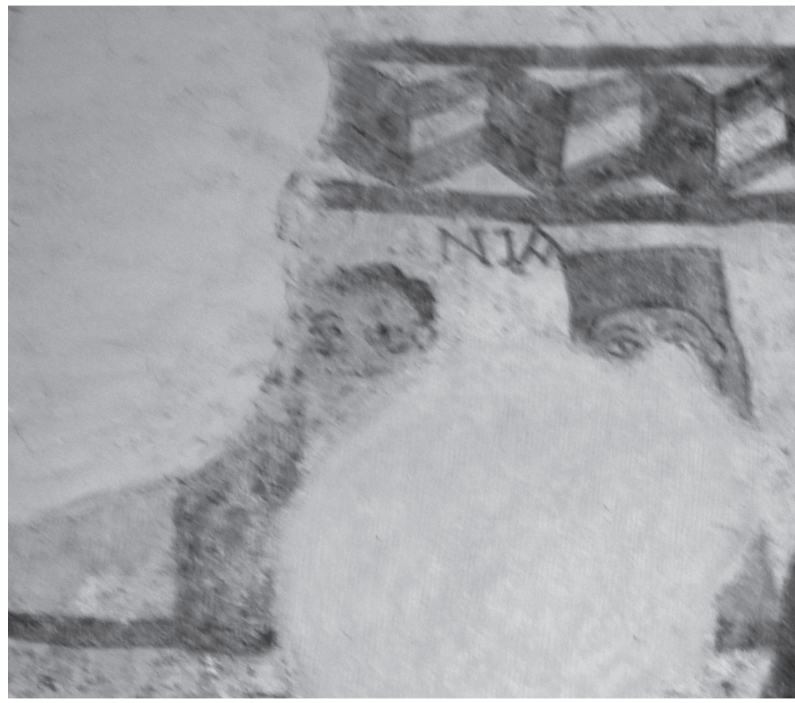

11. Azonosithatatlan jelenet (talán Theotimus és a dajka)

rád várnak a paradicsomnak szent kapui." ${ }^{\prime 77} \mathrm{~A}$ harmadik jelenet (3) is fragmentum: alul, vörös vonal alatt sárkány, a vonalon két figura látható, deréktól lefelé, jobbra fordított lábfejekkel; a jobbra álló Szent Margit (megismerni sárga ruhájáról, kék köpenyéről). Mögötte rövidebb sárga-vörös csíkos tunikát viselő figura áll (7. kép). A legenda szerint ekkor ezt mondta Margit: „Távozz tőlem sátán! És a föld elnyelte öt [ti. a gonoszt]. A következő napon megparancsolta a helytartó, hogy vezessék Boldog Margitot ítélőszéke elé" ${ }^{\prime 48}$ A negyedik jelenet (4) egyetlen figura, sárga ruhában, kék köpenyben, mögötte vékony vonalakkal jelzett emelvény (8. kép). Az alakon rengeteg a retus. A legenda szö- vege: „A helytartó így szólt: Fosszátok meg ruháitól, függesszétek föl a levegőbe és égessétek meg lángoló fáklyákkal" ${ }^{49} \mathrm{Az}$ ötödik jelenet (5) is sérült, de csak az egyik figura feje esett áldozatul. A jelenet Margit kínzását ábrázolja: középütt a szent derékig lemeztelenített alakja, két hosszan lecsüngő hajfonattal. Margit jobbján kék-vörös tunikás, sárgaharisnyás figura, balján vörös nadrágos, szürke harisnyás hóhér ténykedik (9. kép). A legenda ezt így írja le: „A vallatók így is tettek [a helytartó fentebbi parancsát teljesítették]." ${ }^{50}$ Bár ez a jelenet inkább az ostorozást ábrázolja, de a lényeg ugyanaz: Margit kínzása. A következő jelenet (6) kétalakos: balra vonalas emelvényen férfialak ül, előtte Margit erősen retusált, töredékes figurája. Glóriája fölött madár, vörös körvonalakkal, csőrénél kereszt. Itt megmaradtak a feliratok is (10. kép). A kép a következő részletre utal: „.... megparancsolta a prefektus, hogy hozzanak elő egy nagy vízzel teli edényt, kötözzék meg Boldog Margit kezét és lábát, és öljék abba bele. A vallatók úgy cselekedtek, ahogy meghagyták nekik. Boldog Margit az égre pillantva mondta: Uram, te, ki örökké uralkodol, oldd meg az én kötelékeimet, és megszerzem neked a dicsőség áldozatát! Légyen nekem, Uram, e víz a kellemetesség vize. Legyen nekem a fojtogatás az üdvösség világossága, legyen nekem ez a víz a keresztség ki nem apadó forrása! Öltöztess engem az üdvösség sisakjába, jöjjön fölém a te Szentlélekkel teljes szent galambod, áldja meg ezt a vizet a te nevedben, tisztítson meg engem ez a víz az örök életre, és erősítsd meg a lelkem, világosítsd meg az elmém, tisztíts meg bűneimtől." ${ }^{51}$ A következő jelenetből (7) alig maradt valami, csak két fej látszik a cikcakkos parallelogrammás záró sorminta alatt (11. kép). A két fej között betük: NIA. Ez a jelenet talán Margit dajkáját és Theotimust ábrázolhatja, akik kenyeret hoztak Margitnak a börtönbe és szemtanúi voltak az eseményeknek. A következő mezőben (8) egy vörösfehér nadrágos figura kivont kardot tart a jobb kezében, fölötte felirat, két részre bontva: MAL I HU (12. kép). A jelenet a kivégzést ábrázolja „Malchus ezt mondta neki: Nyújtsd ki a nyakad, és fogadd a kardomat, és irgalmazz nekem, mert látom a melletted álló Krisztust az ő angyalaival együtt. Szent Margit ezt válaszolta: Testvérem, kérlek téged, ha látod Krisztust, könyörülj rajtam, míg könyörgök, és a testemet az enyhülés helyére Krisztusnak ajánlom. [...] Ekkor Boldog Margit könyörögni kezdett..." ${ }^{52}$ Mellette (9) a jobb felső sarokban vörös ruhás, kék köpenyes alak, bal kezében könyvet emel a magasba. Feje fölött TEO | TI felirattal. Mellette jobbra egy hasonlóan öltözött figura töredéke (13. kép). „Én [Theotimus] voltam ugyanis az, aki vittem neki a börtönbe kenyeret és vizet, és láttam 


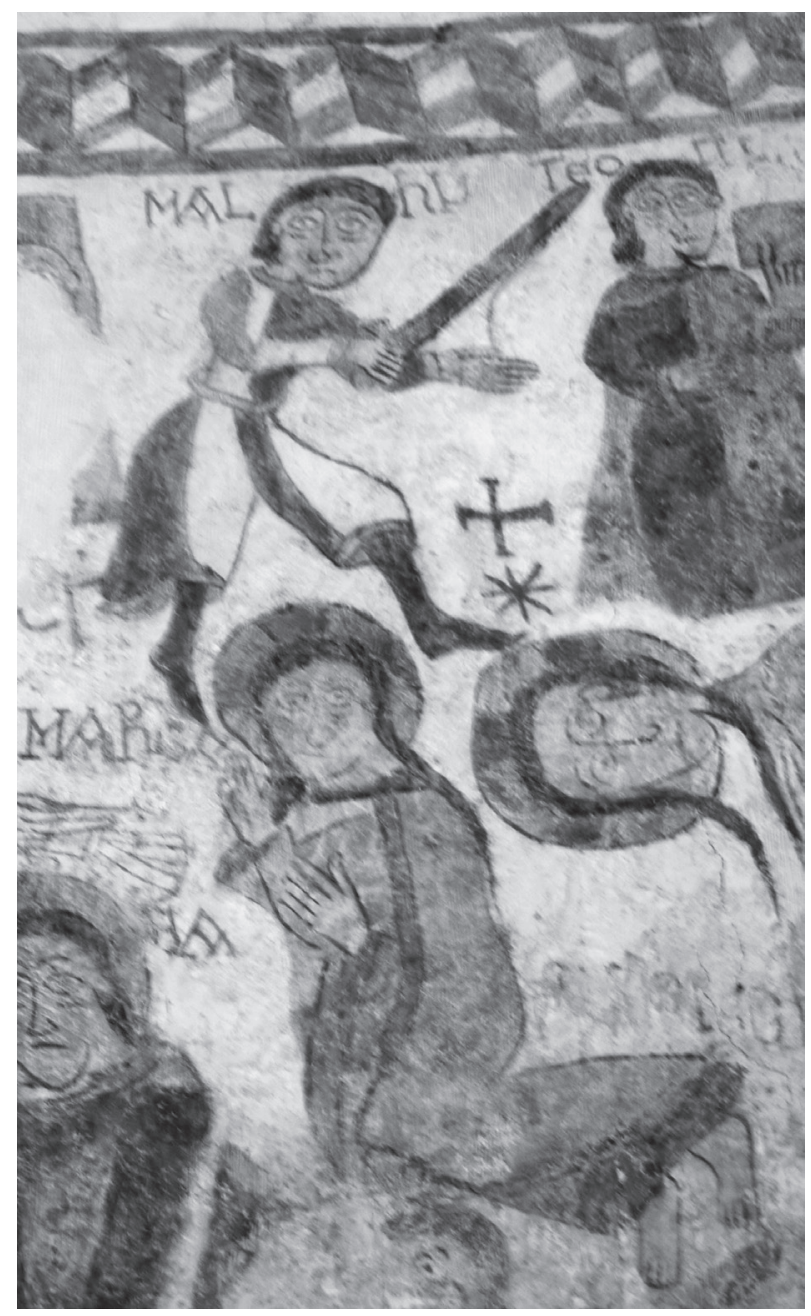

12. Malchus lefejezi Szent Margitot

az egész küzdelmet, melyet a kegyetlen kínzókkal szemben folytatott, és minden könyörgését leírtam egy hártyalapokból álló könyvbe az igazságnak megfelelően...." ${ }^{33}$ Theotimus alatt a vértanúságot szenvedett szent látható, valamint egy kibogozhatatlan jelentésű felirat töredéke (...GIDET ...), amelyet egyelőre a legenda ismerete sem világít meg.

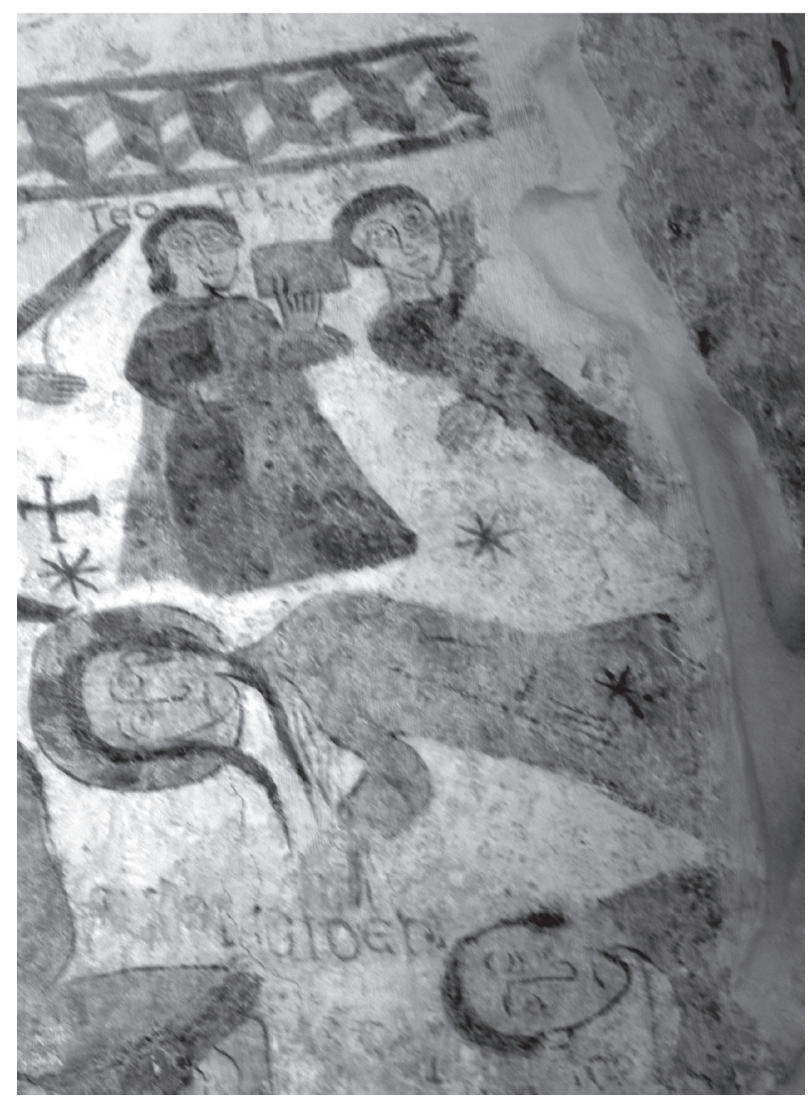

13. Theotimus és a halott Szent Margit

Összegezve az elmondottakat: úgy vélem, hogy a szalonnai falképek programja alapjául a Theotimus-féle legenda szolgálhatott. A jelenetek részletessége és a szöveggel való nagymértékü egyezése azt a benyomást kelti, hogy a hívők a falképek segítségével követni tudták a szent szenvedéstörténetét. Marosi Ernő szavaival „tökéletesen teljesítették emlékeztető-oktató feladatukat." ${ }^{54}$ A középkori falképek feliratainak elemzése és az ábrázolt szentek különböző legendaváltozataival való összevetése még sok újdonságot tartogathat a kutatás számára. ${ }^{55}$

\section{JEGYZETEK}

1 Ezúton is szeretném megköszönni Mikó Árpádnak és Szakács Béla Zsoltnak a dolgozat készítése közben nyújtott tanácsaikat.

2 Uhrin Dorottya: Antiochiai Szent Margit legkorábbi kultusza. Álmos herceg egyházalapításai és a Szent Margit szakramentárium. Magyar Könyvszemle CXXXIII. 2017, 13-31.

3 Uhrin Dorottya: A virgines capitales kultusza a középkori Magyarországon. Budapest 2019. (Kézirat.)

4 M. Kozák Éva: Régészeti kutatások a szalonnai református templomban. A Herman Ottó Múzeum Évkönyve XX. Miskolc 1981, 17; Bécsi János - Pintér Attila: A sza- lonnai református templom falképeinek helyreállítása. A Herman Ottó Múzeum Évkönyve XX. Miskolc 1981, $61-71$.

5 Erről a munkáról sajnos nem áll rendelkezésre dokumentáció. L. erről: Bécsi János - Pintér Attila: A szalonnai református templom... i. m. (4. j.) 61-64.

6 Hokkyné Sallay Marianne: A szalonnai református templom középkori falképei. A Herman Ottó Múzeum Évkönyve XX. Miskolc 1981, 54.

7 Schônerné Pusztai Ilona: Beszámoló a szalonnai református templom felújításairól. In: Détshy Mihály nyolcvanadik születésnapjára. Tanulmányok. (Művészettörténet 
- műemlékvédelem, 11.) Szerk. Bardoly István - Haris Andrea. Budapest 2002, 79-87.

8 A magyarországi müvészet a honfoglalástól a XIX. század végéig. Szerk. Dercsényi Dezső. Budapest $1964^{3}$, 120. L. még: Dercsényi Dezső - Zádor Anna: Kis magyar müvészettörténet. Budapest 1980, 74.

9 Kampis Antal: A magyar művészet a XIX. századig. Budapest 1968, 36.

10 A művészet története Magyarországon. Szerk. Aradi Nóra. Budapest 1983, 51.

11 Galavics Géza - Marosi Ernó - Mikó Árpád - Wehli Tünde: Magyar müvészet a kezdetektől 1800-ig. Budapest 2001, 81-82.

12 Marosi Ernő: A romanika Magyarországon. Budapest 2013, 137.

13 Gervers-Molnár Vera: A középkori Magyarország rotundái. (Müvészettörténeti Füzetek, 4.) Budapest 1972, 34

14 Marosi Ernő: Magyar falusi templomok. (Építészeti hagyományok). Budapest 1975², 30-31, 148.

15 Détshy Mihály: Műemléki templomok. In: Müemlékek Borsod-Abaúj-Zemplén megyében. Miskolc 1987, 45. 164-166. (75-78. képek)

16 Vlasta Dvoŕáková - Josef Krása - Karel Stejskal: Středověká nástěnná mal'ba na Slovensku. Praha-Bratislava 1978, 41; Milan Togner: Stredoveká nástenná mal'ba na Gemeri. Bratislava 1989, 66.

17 Viga Gyula: Százhuszonöt éve született Leszih Andor. Honismeret XXIII. 2005, 4. sz., 8-12.

18 Leszih Andor: A szalonnai templomban árpádkori falfestményeket fedeztek fel. Magyarság IV. 1922. augusztus 10., 6 .

19 Szabó Ferencről: Leszih Andor: A szalonnai templom XIII. századbeli falfestménye. A Herman Ottó Múzeum Évkönyve I. Miskolc 1957, 141.

20 Szabó Ferenc: Borsodmegye Árpád-kori templomai. (A Budapesti Királyi Magyar Pázmány Péter TudományEgyetem Művészettörténeti és Keresztényrégészeti Intézetének dolgozatai, 39.) Miskolc 1936, 37-45.

21 Gerevich Tibor: Magyarország románkori emlékei. Budapest 1938, 228.

22 Kampis Antal: Régi magyar múvészet. In: Magyar Müvelődéstörténet, I. Ósműveltség és középkori kultúra. Szerk. Domanovszky Sándor. Budapest é. n., 502-504.

23 Radocsay Dénes: A középkori Magyarország falképei. Budapest 1954, 27, 212.

24 Leszih Andor: A szalonnai templom XIII. századbeli falfestménye. A Herman Ottó Múzeum Évkönyve I. Miskolc 1957, 141-145.

25 Tóth Melinda: Árpád-kori falfestészet. (Müvészettörténeti Füzetek, 9.) Budapest 1974, 87.

26 Tóth Melinda: Árpád-kori... i. m. (25. j.) 160., 649. j. A Margit-legenda feltételezett szerzőjét nem Theophilusnak, hanem Theotimusnak hívták.

27 Uo. 87. és 160., 650. j.

28 Hokkyné Sallay Mariann: A szalonnai református templom... i. m. (6. j.) 54 .

29 Uo. 57.

30 Zsoldos Attila: Magyarország világi archontológiája, 1000-1301. Budapest 2011, 179.
31 M. Kozák Éva: Régészeti kutatások... i. m. (3. j.) 18 Hokkyné Sallay Mariann: A szalonnai református templom... i. m. (6. j.) 54 .

32 Dorottya Uhrin: The Cult of Saint Dorothy in Medieval Hungary. Budapest, CEU, 2018. (szakdolgozat); Kirsten Wolf: The Icelandic Legend of Saint Dorothy. Toronto 1997.

33 Hokkyné Sallai Marianne: A szalonnai református.. i. m. (6. j.) 55 .

34 Bibliotheca Hagiographica Graeca. Szerk.: F. Halkin. Brussels 1957, 1165. A latin verziói: Bibliotheca Hagiographica Latina, Subsidia Hagiographica 12. Brussels 1898-1901, 5303-5305. Arra, hogy Theotimus szerepel a falképen, Juliana Dresvina is utalt könyvében (Juliana Dresvina: A Maid with a Dragon. The Cult of St Margaret of Antioch in Medieval England. Handbook with Texts. Oxford 2016, 292), ám csupán a mellékletben, a Szent Margit-falképciklusok leírásakor sorolja fel a jelenetet Szalonnánál, de nem fejti ki, hogy miért szerepel Theotimus a képen.

35 Mary Clayton - Hugh Magennis: The Old English Lives of St. Margaret. Cambridge 1944, 6.

36 Hannover, Niedersächsische Landesbibliothek, MS I 189. [eredetileg fuldai kézirat], 970 körül.

37 Verona, Biblioteca Civica di Verona, MS 1853.

38 Juliana Dresvina: A Maid with a Dragon... i. m. (34. j.) 289-298.

39 Érdemes megjegyezni azt is, hogy a jelenetek feliratai általában az alakok fölött vannak.

40 Hasonlóan a Verona, Biblioteca Civica di Verona, MS 1853. ábrázolásaihoz.

41 Tóth Melinda: Árpád-kori... i. m. (25. j.) 160., 644. j.

42 Hokkyné Sallay Marianne: A szalonnai református... i. m. (5. j.) 54 .

43 A süvetei falképek festője feltehetően más előképek alapján dolgozott, így nem hasonlítom össze a két ciklust. A süvetei képek lényegesen jobbak is, mint a szalonnaiak.

44 Juliana Dresvina: A Maid with a Dragon... i. m. (34. j.) 291.

45 Uo. 292.

46 Juliana Dresvina: A Maid with a dragon... i. m. (34. j.) 289-298.

47 A legenda latin verzióját és magyar fordítását 1 . Orbán Imre: „Ecce, iam vici mundum!” Antiochiai Szent Margit tisztelete Magyarországon. Budapest 2001, 177197. Az idézett szöveg a 193. oldalon található.

48 Uo. 194-195.

49 Uo. 195.

50 Uo. 195.

51 Uo. 195

52 Uo. 195

53 Uo. 197.

54 Marosi Ernő: A romanika Magyarországon... i. m. (12. j.) 137.

55 Marosi Ernő: Honora - adora: A veleméri Vera icon felirata. In: Kő kövön. Dávid Ferenc 73. születésnapjára. Stein auf Stein: Festschrift für Ferenc Dávid. Szerk.: Szentesi Edit - Mentényi Klára - Simon Anna. Budapest 2013, 453-458. 


\section{THE LEGEND OF SAINT MARGARET IN THE MURAL PAINTINGS OF THE CALVINIST CHURCH OF SZALONNA}

The present paper analyses the $13^{\text {th }}$-century mural paintings of Szalonna depicting the legend of Saint Margaret on the basis of inscriptions and written versions of the legend. The representations in Szalonna together with the frescoes of Süvete (today Šivetice, Slovakia) constitute the earliest depictions of the saint in Hungary.

The Calvinist Church of Szalonna was formed with the expansion of a round church in the second half of the $13^{\text {th }}$ century. The fragmented legend of Saint Margaret is situated on the southern wall of the round church which was used as its sanctuary. The legend was depicted before the rebuilding of the church in the $13^{\text {th }}$ century. The mural paintings were found in 1922 and renovated in 1951 and 1972. The art historical literature is aware of the mural paintings and has formed a negative opinion about their quality, style, and the iconographical knowledge of the painter. According to the literature, some of the scenes were borrowed from either the legend of Saint Dorothy or the legend of the Virgin Mary, while other scenes could not be identified.

The present paper shows that the scene which was believed to be borrowed from the legend of Saint Dorothy was actually part of the legend of Margaret. The inscription of the scene was misinterpreted earlier; it was read as Teofi[1] instead of Teoti[mus]. With the help of this and an inscription (Malhu[s]) from another scene of the legend, it could be identified that the depiction of the legend is based on the passio a Theotimo, an early version of Saint Margaret's legend. The scenes closely adhere to the written version, which sheds light on the fact that almost half or one third of the representation of Szalonna have been lost. This is evident because the scenes start with the appearance of the devil in the form of a man. It would worthwhile to carefully scrutinize the inscriptions of the Hungarian frescoes and compare them to different written versions of the legends of saints, because they can reveal novelties.

UHRIN Dorottya történész, ELTE BTK Középkori Történeti Tanszék, tudományos segédmunkatárs / historian, Eötvös Loránd University, assistant research fellow at Medieval History Department

Kulcsszavak: szalonnai református templom, Antiochiai Szent Margit, romanika Magyarországon, szentkultusz, falfestészet / Key words: the Calvinist Church of Szalonna, Saint Margaret of Antioch, Romanesque art in Hungary, cult of saints, mural painting 